\title{
Effects of environmental factors on morphological and quality parameters of table beet root
}

\author{
Takács-Hájos, M. \& Rubóczki, T. \\ University of Debrecen, Centre of Agricultural Science and Engineering, Faculty of Agriculture, \\ Institute of Horticulture, 138. Böszörményi str., Debrecen, H-4032, Hungary \\ e-mail:hajos@agr.unideb.hu
}

\begin{abstract}
Summary: In our trial morphological and quality parameters of 15 table root varieties were tested at 3 different sowing dates: 15 April, 9 July and 19 August 2010.

In the trials the root shape of the varieties form the April sowing date approached most the regular spherical shape (diameter/length -1.0) which is favoured both by fresh market and the processing industry. In the July and August sowings the roots were elongated with reduced proportions.

The highest red pigment content (betacyanin) was observed in the second sowing of July (>80 mg/100 g). In the late sowing (August, under plastic tent) a further $10-20 \mathrm{mg} / 100 \mathrm{~g}$ pigment increase was measured in relation to the earlier sowing dates of the same varieties. A similar trend could be observed in yellow pigments (vulgaxanthis) which proves a close correlation between the quantities of the 2 pigments $(\mathrm{r}=0.823)$. The highest vulgaxanthin content $(103.3-124.18 \mathrm{mg} / 100 \mathrm{~g})$ was obtained form roots of the late sowing harvested in December. Varieties reacted differently to temperature and so to sugar accumulation in the different sowing periods. In the July sowing higher water soluble solids content was measured on the mean of varieties (10.12\%) as compared to the April sowing (7.76\%).

Sensory evaluations included inner colour intensity (1-5), with ring (1-3) and taste (1-5) of the raw material evaluated by scoring. According to laboratory measurements better inner colour intensity was observed in the July and August sowing dates. In these samples uniformly coloured, almost with, ring-free roots were obtained. In our trial varieties from the spring sowing had superior taste. Early sowing is recommended for fresh market sale while the second crop (July) harvested in autumn can satisfy processing requirements. In the late sowing (under unheated plastic tent) fresh beet root can be grown at the end of autumn or beginning of winter, thus prolonging the usability of plastic tents.
\end{abstract}

Key words: sowing date, table beet root varieties, colour and solid content, betacyanins, vulgaxanthins, sensory evaluation

\section{Introduction}

Formerly a medicinal plant and now generally used as a vegetable crop table beet root could fully answer modern raw material requirements of the food industry being a natural colouring agent. It is widely used abroad to substitute for the artificial and carcinogen agent E123. The high curative effect is mostly due to its rich vitamin and mineral ontents. Remarkable is the high mineral element content of the root and leaves (Stefanovits Bányai et al., 2002) which contributes to the mineral balance of the human organism by strengthening muscles and stamina. Antioxidants, vitamins $\mathrm{B}$ and $\mathrm{C}$, pigments and other bioactive compounds are also found (Goldman and Navazio, 2008).

Despite its favourable effect on the human body table beet root occupies a relatively small growing area (cca. $0.3 \%$ of the total vegetable area). In Europe it is more widely used: fresh, salads, components of soups and dessert.

The trial aimed at testing the interaction of varieties and environmental factors on quality parameters at different sowing dates. In the same time suggestions are made how to use beet root harvested at different times according to its quality.

\section{Literary review}

Table beet root belongs to the cold tolerant species, its heat optimum being $19 \pm 7^{\circ} \mathrm{C}$ after Markov-Haev. This temperature interval favours pigment development. Accordingly, in the countries north of Hungary beet root is grown and bred on much larger areas with considerably greater economical importance than in our country. In Hungary beet root is mostly known as canned salad from autumn processing. Researches of the past years confirmed its favourable nutritional-physiological effects so demands, as for fresh salad, also increased. Raw material requirements cannot be satisfied either as used to do up to now. Spring (April) and late (August, under plastics) sowings are well justified. Due to the short growing period (100 days) marketable yield can be obtained in July from spring sowing, in October form the second crop and in December form the late sowing under plastics.

Of the applied methods the early sowing (April) can be mentioned which can be harvested by the end of July but only for fresh market sale.

In Hungary table beet root is generally sown as second crop (end of June, beginning of July) because of the short 
growing period (100-110 days) and autumn processing capacity. In these months successful production cannot be without irrigation. Even water supply is absolutely necessary otherwise white ring will form and the bottom root will thicken and cause loss in cleaning.

The effect of sowing dates is influenced considerably by the climatic factors of the production area. German trials (Erfurt) showed the highest yield and best quality (low nitrate content) in early (April) sowing while the yield of the June sowing lagged behind (46\%) that of the earlier crops. Moreover, the nitrate content also reached $3027 \mathrm{mg} / \mathrm{kg}$ value. Sowing dates hardly influenced the water soluble solids content (Feller and Fink, 2004).

The produce baby beet root and bunched beet root for fresh market seeds were sown early in spring in beds with 200 plant $/ \mathrm{m}^{2}$ using cold tolerant, bolting resistant, quickly thickening varieties. Considering the small root size production can only be profitable if the proportion of the desired root size reaches monogerm seeds, precise sowing and uniform germination (Takacs-Hajos et al., 2008).

Unheated plastic tents can be utilized in August sowing for some cold tolerant species including table beet root with quick vigorous growth and short growing period. Temporary cool periods could be parried by using voile covering.

The most important quality parameters include inner colour intensity and uniformity and water soluble solids content. There are considerable differences among varieties (Takácsné Hájos, 1999). One of the unfavourable traits is white ring. Some varieties are susceptible but the occurrence can be reduced considerably by proper cultural methods.

The favourable dietaryphysiological effect is guaranteed by the red pigment (betacyanins), mineral element and diatetic fibre contents. Red pigments are found in several components which are present in different proportions in the varieties. They also determine the pigment compositions and their stability (Nagy-Gasztonyi et al., 2001).

In the water extract of the beet root the totality of pigments is called betalains. The compounds consist of the yellow pigments vulgaxanthin I, vulgaxanthin II and indica xanthin while betanin, prebetanin, isobetanin and neobetanin are responsible for the red colour. Glucose is an important component in the biosynthesis of red and yellow pigments. Thus, the quality of these 2 compound groups correlates with the rate of sugar accumulation (Mabry, 1980). In the growing period pigments keep on accumulating till the $100^{\text {th }}$ day than after the $130^{\text {th }}$ day, they can decline even by $40 \%$ (Shannon, 1972; Takácsné-Hájos, 1997a).

Information about the antitumor effect of table root accelerated the testing of its bioactive components. This special effect is attributed to the red pigment content, to lactic acid in the fermented product and to certain vitamins (C and E). Rusic at al. (1983) reported antitumor effects of the fermented beet root juice. Lipid metabolism was also found favourably affected (Váli et al., 2007).

Beet root contains numerous vital macro- and microelements: fibres (0.9-2.53\%), potassium (336 mg/100 g), magnesium $(25 \mathrm{mg} / 100 \mathrm{~g})$. The total sugar content $(3.5-$ $8.5 \%$ ) consist of $92-95 \%$ sucrose and only $5-8 \%$ simple sugar. It depends on the variety, environmental factors and sowing and harvest dates (Takacs-Hajos, 2009; Sumrah et al., 2003). Beside sugars the taste of beet root is also determined by geosmin, it is responsible for its characteristic earthy taste. The soil and the variety both take part in the accumulation of this compound (Guiping et al., 2003). There are, however, considerable differences among varieties. But unsuitable storage conditions (nylon sacks, $10{ }^{\circ} \mathrm{C}$ temperature) can make the situation even worse (Takácsné-Hájos, 1997b).

\section{Materials and methods}

Tests were set up in the Horticultural Demonstration Garden of the Centre for Agricultural and Applied Economic Sciences of the University Debrecen with 15 table beet root varieties at 3 sowing dates (15 April, 9 July, 19 August). Soil analysis data of the area are given of the Institute for Food Science, Quality Safeguard and Microbiology of the University (Table 1).

Table 1. Soil analysis results

\begin{tabular}{|c|c|c|c|c|c|}
\hline $\mathrm{pH}_{\mathrm{H}_{2} \mathrm{O}}$ & $\mathbf{p H}_{\mathrm{KCl}}$ & $\begin{array}{c}\text { Humus } \\
(\%)\end{array}$ & $\begin{array}{c}\text { Total N } \\
(\%)\end{array}$ & $\begin{array}{c}\mathrm{P}_{2} \mathrm{O}_{5} \\
(\mathrm{mg} / \mathrm{kg})\end{array}$ & $\begin{array}{c}\mathrm{K}_{2} \mathrm{O} \\
(\mathrm{mg} / \mathrm{kg})\end{array}$ \\
\hline 7,75 & 7,27 & 5,39 & 0,313 & 140,8 & 230 \\
\hline 7,87 & 7,29 & 2,36 & 0,137 & 126,2 & 260 \\
\hline
\end{tabular}

Data reveal that $\mathrm{pH}$ values, humus content and $\mathrm{K}$ supply of the soil satisfy beet root requirements.

During the growing period productivity and quality parameters of the varieties were observed. Table 2 lists the tested varieties according to sowing dates.

Figure 1 shows meteorological data. For measurements instruments of the University were used (Institute for Land Utilization, Technics and Area Development).

Table beet root varieties were first sown 15 April 2010 in 3 repetitions with 13 varieties at $30 \mathrm{~cm}$ row distance.

During the growing period the usual cultural and weeding methods were used. Plants were thinned at the 2-4 leaf stage 26 May 2010. Only 2 supplemental irrigations (30 mm) were needed as daily temperature and natural precipitations guaranteed optimal growing conditions. Crop was harvested 21 July 2010. Field measurements and sensory evaluation included: leaf length $(\mathrm{cm})$, leaf weight $(\mathrm{g})$, root diameter $(\mathrm{cm})$, root length $(\mathrm{cm})$, root weight $(\mathrm{g})$, inner colour intensity $(1-5)$, white ring (1-3) and taste (1-5). Pigment content (mg/100 g) was measured in the laboratory of the Institute for Food and Science, Quality Safeguard and Microbiology of the University with spectrophotometer at $\lambda=476 \mathrm{~nm}, \lambda=538 \mathrm{~nm}$ and $\lambda=600 \mathrm{~nm}$ 


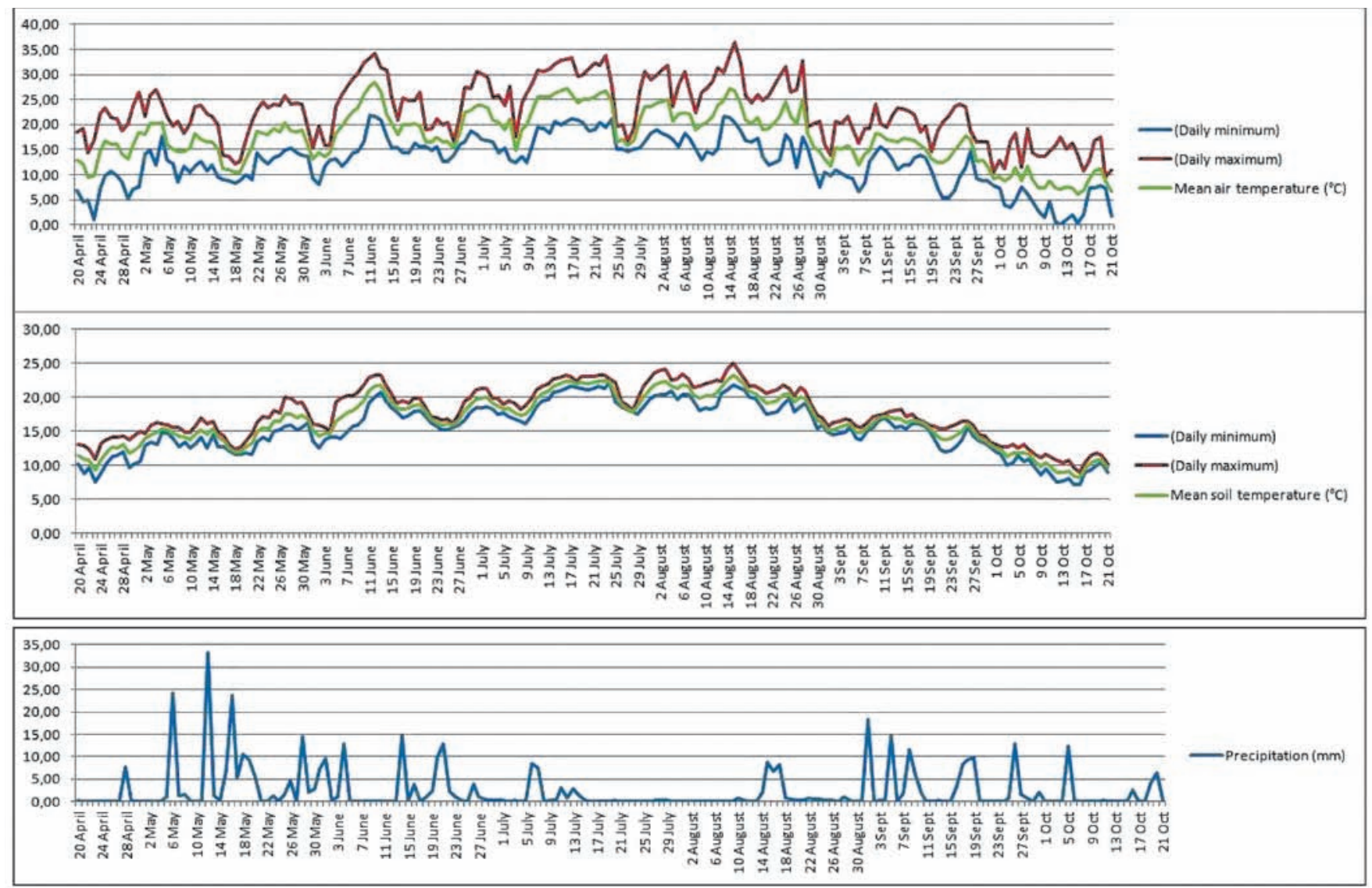

Figure 1. Soil, air and precipitation data in the tested period Debrecen April - October 2010

Table 2. Varieties in the different sowing dates

\begin{tabular}{|c|c|c|c|c|}
\hline \multirow{2}{*}{$\begin{array}{c}\text { Series } \\
\text { number }\end{array}$} & \multirow{2}{*}{ Variety } & \multicolumn{3}{|c|}{ Sowing date } \\
\hline & & 15 April & 9 July & 19 August \\
\hline 1. & Detroit* & $\mathrm{X}$ & $\mathrm{X}$ & - \\
\hline 2. & Bordó & $\mathrm{X}$ & $\mathrm{X}$ & - \\
\hline 3. & Favorit & $\mathrm{X}$ & $\mathrm{X}$ & - \\
\hline 4. & Bonel & $X$ & $\mathrm{X}$ & $\mathrm{X}$ \\
\hline 5. & Rubin & $X$ & $\mathrm{X}$ & - \\
\hline 6. & Little Ball & $\mathrm{X}$ & $\mathrm{X}$ & - \\
\hline 7. & Akela & $\mathrm{X}$ & $\mathrm{X}$ & $\mathrm{X}$ \\
\hline 8. & Larka & $X$ & $X$ & $\mathrm{X}$ \\
\hline 9. & Libero & $\mathrm{X}$ & $\mathrm{X}$ & $\mathrm{X}$ \\
\hline 10. & Mona Lisa & $\mathrm{X}$ & $\mathrm{X}$ & $\mathrm{X}$ \\
\hline 11. & Bikores & $\mathrm{X}$ & $\mathrm{X}$ & - \\
\hline 12. & Egyiptomi lapos & $\mathrm{X}$ & $\mathrm{X}$ & - \\
\hline 13. & Konett & $\mathrm{X}$ & $\mathrm{X}$ & - \\
\hline 14. & Cylindra* & - & $\mathrm{X}$ & - \\
\hline 15. & Cvikla podhlovaska* & - & $\mathrm{X}$ & - \\
\hline
\end{tabular}

*due to deficient coming up only some individuals could be evaluated sensorially wavelength. The pigment content was determined according to Nilsson (1970) from the obtained extinction values. Statistical analysis included (Sváb, 1981) 2-factor variance analyses and correlation calculations (Microsoft Excel).

The second sowing followed 9 July 2010 in 4 repetitions with 15 varieties using usual cultural methods. Due to the warm, dry weather irrigation had to be applied 6 times (30 $\mathrm{mm}$ water dose). Daily mean temperature varied greatly during the growing period morphological and sensory evaluations the methods described above were used.

The third test was sown 19 August 2010 with 5 varieties under unheated plastic (movable) tents in 3 rows for each variety and at $30 \mathrm{~cm}$ row distance.

Regular irrigation, soil loosening and weeding methods were applied. Roots were harvested and evaluated 7 December 2010.

\section{Results and evaluation}

\section{Root morphology}

Quality is affected considerably by the morphological traits. The tested varieties were all of the spherical type except for Egyiptomi lapos. The spherical or slightly flatted root shape is responsible for an attractive appearance. Diameter, length and weight of roots were determined at 3 different sowing dates: spring (15 April), second crop (9 July) and late (19 August) (Table 3). 
Table 3. Morphological data of the tested varieties

\begin{tabular}{|l|c|c|c|c|c|c|c|c|c|}
\hline \multirow{2}{*}{\multicolumn{1}{|c|}{ Variety }} & \multicolumn{3}{|c|}{ Diameter (cm) } & \multicolumn{3}{c|}{ Length (cm) } & \multicolumn{3}{c|}{ Weight (g) } \\
\cline { 2 - 12 } & $\mathbf{1 5}$ April & 9 July & 19 August & 15 April & 9 July & 19 August & 15 April & 9 July & 19 August \\
\hline Bordó & 6.54 & 5.88 & & 7.93 & 6.91 & & 182.40 & 164.22 & \\
\hline Favorit & 6.94 & 6.10 & & 6.44 & 6.60 & & 161.00 & 170.10 & \\
\hline Bonel & 6.34 & 5.20 & 4.75 & 7.38 & 6.35 & 5.50 & 141.40 & 112.50 & 109.4 \\
\hline Rubin & 5.92 & 5.45 & & 6.09 & 6.05 & & 131.93 & 103.30 & \\
\hline Little Ball & 6.30 & 6.18 & & 6.81 & 6.95 & & 172.93 & 166.98 & \\
\hline Akela & 6.13 & 6.48 & 5.20 & 6.48 & 7.30 & 6.38 & 149.33 & 187.60 & 91.73 \\
\hline Larka & 5.74 & 5.20 & 4.90 & 6.07 & 5.53 & 6.50 & 93.73 & 88.93 & 85.68 \\
\hline Libero & 5.94 & 6.33 & 5.67 & 6.47 & 7.07 & 7.00 & 140.67 & 161.13 & 156.95 \\
\hline Mona Lisa & 5.85 & 5.20 & 5.60 & 5.57 & 6.00 & 7.00 & 143.05 & 111.10 & 96.00 \\
\hline Bikores & 6.92 & 5.63 & & 6.71 & 6.43 & & 185.27 & 148.17 & \\
\hline Egyiptomi lapos & 7.50 & 7.50 & & 5.22 & 5.83 & & 207.25 & 198.67 & \\
\hline Konett & 5.84 & 5.00 & & 6.32 & 6.60 & & 139.54 & 127.97 & \\
\hline mean & 6.33 & 5.85 & 5.22 & 6.46 & 6.47 & 6.48 & 154.04 & 145.06 & 107.95 \\
\hline deviation & 0.55 & 0.72 & 0.41 & 0.73 & 0.54 & 0.61 & 29.90 & 35.45 & 28.74 \\
\hline
\end{tabular}

Roots sown in April were larger in diameter and heavier in weight than those sown in July which can be explained by the sufficient natural water supply $(269.40 \mathrm{~mm})$ of the period between April and July. In the second crop only $230.80 \mathrm{~mm}$ precipitation was measured during the 100 day growing period with $27{ }^{\circ} \mathrm{C}$ mean temperature in August. In August beet root was sown under an unheated plastic tent to protect it from frosts during the 100 day growing period. In the 5 varieties roots were smaller and weighted less. Shape index of the varieties is shown in Table 4.

Table 4. Beet root shape index - diameter $(\mathrm{cm}) /$ length $(\mathrm{cm})$

\begin{tabular}{|l|c|c|c|c|c|}
\hline \multicolumn{1}{|c|}{ Variety } & 15 April & 9 July & 19 August & $\begin{array}{c}\text { Shape } \\
\text { index on } \\
\text { the mean } \\
\text { of sowing } \\
\text { dates }\end{array}$ & Distribution \\
\hline Bordó & 0.82 & 0.85 & & 0.84 & 0.02 \\
\hline Favorit & 1.08 & 0.92 & & 1.00 & 0.11 \\
\hline Bonel & 0.86 & 0.82 & 0.86 & 0.84 & 0.02 \\
\hline Rubin & 0.97 & 0.90 & & 0.94 & 0.05 \\
\hline Little Ball & 0.93 & 0.89 & & 0.91 & 0.03 \\
\hline Akela & 0.95 & 0.89 & 0.82 & 0.92 & 0.06 \\
\hline Larka & 0.95 & 0.94 & 0.75 & 0.94 & 0.11 \\
\hline Libero & 0.92 & 0.90 & 0.81 & 0.91 & 0.06 \\
\hline Mona Lisa & 1.05 & 0.87 & 0.80 & 0.96 & 0.13 \\
\hline Bikores & 1.03 & 0.88 & & 0.95 & 0.11 \\
\hline Egyipt. lapos & 1.44 & 1.29 & & 1.36 & 0.11 \\
\hline Konett & 0.92 & 0.76 & & 0.84 & 0.12 \\
\hline $\begin{array}{l}\text { Shape index on } \\
\text { the varieties }\end{array}$ & 0.99 & 0.91 & 0.81 & & \\
\hline deviation & 0.16 & 0.13 & 0.04 & & \\
\hline
\end{tabular}

\section{Quality parameters}

The raw material value of table beet root is determined principally by the pigment content, its even distribution and the correlation of the red (betacyanin, BC) and yellow (betaxanthin, $\mathrm{BX}$ ) pigments to each other. The most important pigment component is the betanin, a compound of red betacyanins occurring in the highest ratio. Data are shown in Figure 2.

The majority of varieties show higher values in the second crop than in the spring crop. The higher betanin content was promoted, without doubt, by the lower air temperature at the time of root thickening (September, in the second crop). The spring crop was harvested 21 July when temperature above $30{ }^{\circ} \mathrm{C}$ were measured. The Fig. shows clearly that the betanin content of root from the late showing date surpassed that of the 


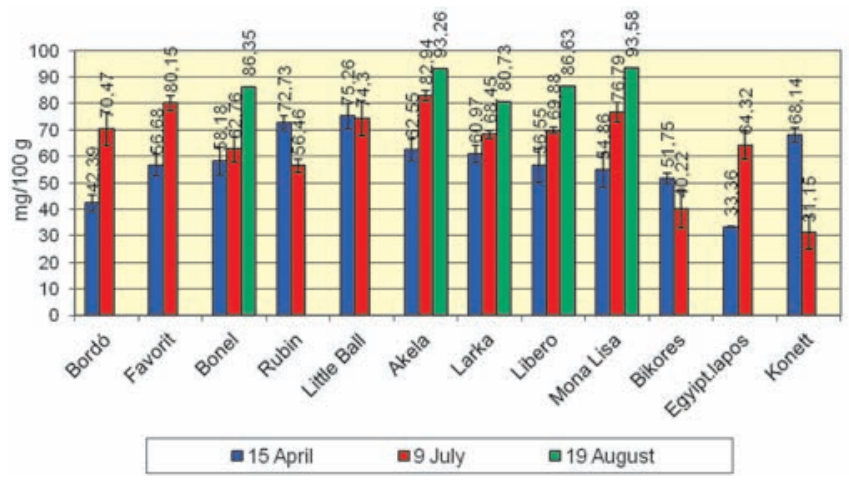

Figure 2. Betanin content $(\mathrm{mg} / 100 \mathrm{~g})$ of beet root varieties at different sowing dates

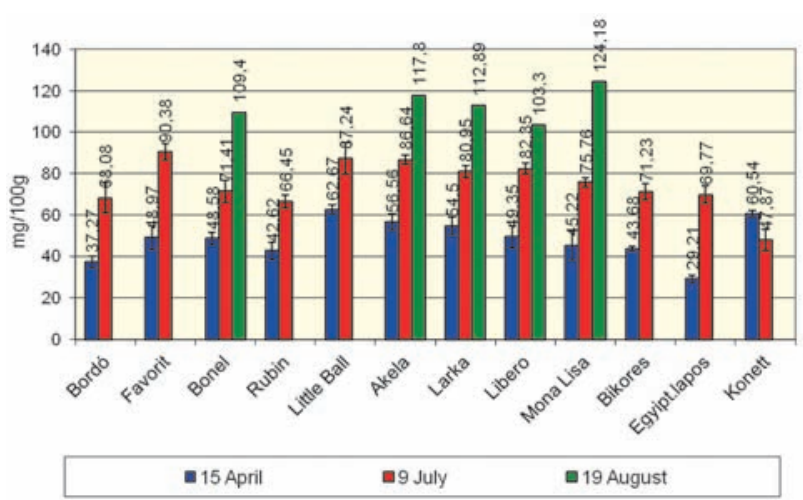

Figure 3. Vulgaxanthin content $(\mathrm{mg} / 100 \mathrm{~g})$ of table beet root varieties at different sowing dates

Table 5. Correlation studies between beet root quality parameters

\begin{tabular}{|c|c|c|c|c|c|c|c|c|}
\hline & BC & BX & $\mathrm{BC} / \mathrm{BX}$ & $\begin{array}{c}\text { Water } \\
\text { soluble } \\
\text { solids }\end{array}$ & Total solids & $\begin{array}{c}\text { Inner colour } \\
(1-5)\end{array}$ & $\begin{array}{c}\text { White ring } \\
\text { (1-3) }\end{array}$ & $\begin{array}{l}\text { Taste } \\
(1-5)\end{array}$ \\
\hline $\mathrm{BC}$ & 0 & 0.823 & -0.225 & 0.317 & 0.259 & 0.361 & 0.282 & 0.281 \\
\hline $\mathrm{BX}$ & & 0 & -0.664 & 0.51 & 0.281 & 0.383 & 0.452 & 0.038 \\
\hline $\mathrm{BC} / \mathrm{BX}$ & & & 0 & -0.587 & -0.08 & -0.151 & -0.414 & 0.197 \\
\hline Water soluble solids & & & & 0 & 0.382 & 0.098 & 0.319 & -0.169 \\
\hline Total solids & & & & & 0 & -0.133 & -0.024 & 0.336 \\
\hline Inner colour (1-5) & & & & & & 0 & 0.73 & 0.047 \\
\hline White ring (1-3) & & & & & & & 0 & -0.115 \\
\hline Taste (1-5) & & & & & & & & 0 \\
\hline
\end{tabular}

earlier showings. It means that the cooler temperature affects the pigment synthesis favourably. Tests of this kind could make suggestions as what genotype to choose for given soil and climatic conditions for fresh market and processing production.

Beside the red betanin the second most important pigment component is the yellow vulgaxanthin (Figure 3).

Sometimes the yellow pigment content (vulgaxanthin) of the beet root sown in July surpassed by more than 50 $\%$ that of the spring crop. In the late (August) sowing very high values were measured similar to the red pigments. This striking increase can also be explained by the cooler autumn weather, it means that the biosynthesis of the two pigment groups runs parallel to each other. The vulgaxanthin content correlation studies showed close correlation in the evolution of yellow and red pigments $(\mathrm{r}=0.823)$ in the tested varieties (Table 5).

The visible inner colour intensity of the root is determined by the relation of the 2 big pigment groups (betacyanins, betaxanthins) to each other $(\mathrm{BC} / \mathrm{BX}$ ratio). This ratio is considerably higher in the spring sowing than in the second or late sowings (Table 6). The difference between the BC/BX ratios observed in the April and July sowings is statistically proved on the mean of varieties (LSD $0.1 \%$ ). It means that the cooler air temperature during the second and late
Table 6. Evolution in betanin and vulgaxanthin $(\mathrm{BC} / \mathrm{BX})$ ratio

\begin{tabular}{|c|c|c|c|}
\hline \multirow{2}{*}{ Variety / sowing date } & \multicolumn{3}{|c|}{$\mathrm{BC} / \mathrm{BX}$ pigment ratio } \\
\hline & 15 April & 9 July & 19 August \\
\hline Bordó & 1,14 & 1,03 & \\
\hline Favorit & 1,16 & 0,89 & \\
\hline Bonel & 1,20 & 0,88 & 0,80 \\
\hline Rubin & 1,00 & 0,85 & \\
\hline Little Ball & 1,20 & 0,85 & \\
\hline Akela & 1,11 & 0,96 & 0,79 \\
\hline Larka & 1,12 & 0,85 & 0,71 \\
\hline Libero & 1,15 & 0,85 & 0,84 \\
\hline Mona Lisa & 1,21 & 1,01 & 0,75 \\
\hline Bikores & 1,18 & 0,56 & \\
\hline Egyiptomi lapos & 1,14 & 0,92 & \\
\hline Konett & 1,13 & 0,65 & \\
\hline mean & 1,15 & 0,86 & 0,78 \\
\hline deviation & 0,06 & 0,14 & 0,05 \\
\hline $\operatorname{LSD}(0,1 \%) * * *$ & \multicolumn{2}{|c|}{0,160} & \\
\hline $\operatorname{LSD}(1 \%) * *$ & \multicolumn{2}{|c|}{0,119} & \\
\hline $\operatorname{LSD}(5 \%) *$ & \multicolumn{2}{|c|}{0,088} & \\
\hline $\operatorname{LSD}(1 \%) * *$ & \multicolumn{3}{|c|}{0,131} \\
\hline $\operatorname{LSD}(5 \%) *$ & \multicolumn{3}{|c|}{0,090} \\
\hline
\end{tabular}


sowings also affected the synthesis of the yellow pigments more favourably. Due to the higher yellow pigment amount lower $\mathrm{BC} / \mathrm{BX}$ ratio was obtained than in the spring sowing which developed in hot air summer days. The $\mathrm{BC} / \mathrm{BX}$ ratio of the August sowing continued decreasing proving a higher development rate of the yellow pigments in relation to the red ones. In the late sowing root thickness and pigment accumulation coincided in October when air temperature decreased below $10{ }^{\circ} \mathrm{C}$. Our tests proved statistically significant differences between the July and August crops in the $\mathrm{BC} / \mathrm{BX}$ ratio ( $\mathrm{LSD} 1 \%$ ). That is, the $\mathrm{BC} / \mathrm{BX}$ ratio of the late autumn crop was essentially lower $(0.78)$ than that of the July sown genotypes (0.86).

In the total solids content of plants distinction must be made between water soluble solids (sugars, pigments, etc.) and water insoluble solids (fibres and other compounds). Water soluble solids were determined by a Brix meter. A considerable part of such substances consists of sugars which are in correlation with the sweet taste of the root. Water soluble solids data in the spring and second crops are shown in Table 7. On the mean of varieties there was significant difference between the second crop (10.12\%) and the spring crop $(7.76 \%)$. Similar significant difference was found among varieties on the mean of sowing dates (Table 8). Favorit and Akela showed the highest values (10,22\% and $9,97 \%$ ). The lowest water soluble solids content was found in Larka and Libero $(7.46 \%$ and $7.17 \%$ ) on the mean of the 2 sowing dates. The highest ref. \% was measured in almost every variety of the July sowing.

Table 7. Evolution of water soluble solids in beet root

\begin{tabular}{|c|c|c|c|}
\hline & \multicolumn{2}{|c|}{$\begin{array}{c}\text { Water soluble solids } \\
\text { (ref.\%) }\end{array}$} & \multirow{2}{*}{$\begin{array}{c}\begin{array}{c}\text { On the } \\
\text { mean of } \\
\text { sowing } \\
\text { dates }\end{array} \\
19 \text { August }\end{array}$} \\
\hline $\begin{array}{l}\text { Variety (A) / } \\
\text { Sowing data (B) }\end{array}$ & 15 April & 9 July & \\
\hline Bordó & 7,47 & 10,46 & 8,97 \\
\hline Favorit & 8,07 & 12,37 & 10,22 \\
\hline Bonel & 8,2 & 11,09 & 9,65 \\
\hline Rubin & 7,9 & 10,3 & 9,10 \\
\hline Little Ball & 7,52 & 10,13 & 8,83 \\
\hline Akela & 9,17 & 10,76 & 9,97 \\
\hline Larka & 6,83 & 8,09 & 7,46 \\
\hline Libero & 6,2 & 8,13 & 7,17 \\
\hline Mona Lisa & 7,7 & 10,03 & 8,87 \\
\hline Bikores & 8,2 & 9,87 & 9,04 \\
\hline Egyiptomi lapos & 7,65 & 10,03 & 8,84 \\
\hline Konett & 8,2 & 10,17 & 9,19 \\
\hline On the mean of varieties & 7,76 & 10,12 & \\
\hline
\end{tabular}

Table 8. Variance table for water soluble solids

\begin{tabular}{|c|c|c|c|c|}
\hline \multicolumn{5}{|c|}{ Variance table (random block) - WATER SOLUBLE SOLIDS } \\
\hline Factor & SQ & FG & MQ & $\mathbf{F}$ \\
\hline Total: & 175.09 & 71 & & \\
\hline Repetition: & 0.16 & 2 & & \\
\hline Treatment: & 162.69 & 23 & 7.07 & $26.58 * * *$ \\
\hline Factor A: & 51.73 & 11 & 4.70 & $17.67 * * *$ \\
\hline Factor B: & 100.25 & 1 & 100.25 & $376.75 * * *$ \\
\hline Factors A B: & 10.70 & 11 & 0.97 & $3.66 * * *$ \\
\hline Error: & 12.24 & 46 & 0.27 & \\
\hline$* * * * \mathrm{P}=0,1 \%$ & \multicolumn{2}{|c|}{$* * * \mathrm{P}=1 \%$} & $* * \mathrm{P}=5 \%$ & $* \mathrm{P}=10 \%$ \\
\hline \multicolumn{5}{|c|}{ Significant differences: } \\
\hline \multicolumn{4}{|c|}{ Between any 2 combinations $(\mathrm{P}=5 \%)$ : } & 0.85 \\
\hline \multicolumn{4}{|c|}{ Between A factor variants on the mean of $\mathrm{B}(\mathrm{P}=5 \%)$ : } & 0.60 \\
\hline \multicolumn{4}{|c|}{ Between $\mathrm{B}$ factor variants on the mean of $\mathrm{A}(\mathrm{P}=5 \%)$ : } & 0.24 \\
\hline \multicolumn{4}{|c|}{$\begin{array}{l}\text { Between differences (e.g. b1-b2 in different A variants) } \\
(\mathrm{P}=5 \%) \text { : }\end{array}$} & 1.20 \\
\hline
\end{tabular}

Beside sugars total solids content also comprises considerable amount of fibres which also play part in root texture. The total solids content (partly fibres) of the root is a variety characteristic but it is also influenced by environmental factors. Of the tested varieties significant difference were found in the genotypes Akela, Larka and Konett between the 2 sowing dates (Table 9-10). In this case the raw material of the spring sowing had higher solids content $(14.21 \%$, $10.83 \%$ and $12.78 \%)$ than that of the second crop $(10.33 \%$, $9.84 \%$ and $9.68 \%$ ) in the 3 varieties. On the contrary, Favorit, Bikores and Egyiptomi lapos showed opposite trends. Such evolution of the solids content is certainly genetically fixed but it is also influenced by temperature and soil humidity. The late (August) sowing showed considerable increase in the 5 varieties as compared to the spring and summer crop.

Table 9. Total solids content of beet root at different sowing dates

\begin{tabular}{|l|c|r|c|}
\hline \multirow{2}{*}{$\begin{array}{c}\text { Variety (A) / Sowing } \\
\text { date (B) }\end{array}$} & \multicolumn{2}{c|}{$\begin{array}{c}\text { Total solids content } \\
\text { (m/m\%) }\end{array}$} & $\begin{array}{c}\text { On the mean } \\
\text { of sowing date }\end{array}$ \\
\cline { 2 - 4 } & $\mathbf{1 5}$ April & 9 July & 19 August \\
\hline Bordó & 12,11 & 12,3 & 12,21 \\
\hline Favorit & 12,83 & 14,28 & 13,56 \\
\hline Bonel & 12,79 & 12,19 & 12,49 \\
\hline Rubin & 12,16 & 12,5 & 12,33 \\
\hline Little Ball & 12,25 & 12,62 & 12,44 \\
\hline Akela & 14,21 & 10,33 & 12,27 \\
\hline Larka & 10,83 & 9,84 & 10,34 \\
\hline Libero & 9,88 & 9,68 & 9,78 \\
\hline Mona Lisa & 12,08 & 12,41 & 12,25 \\
\hline Bikores & 13,33 & 14,12 & 13,73 \\
\hline Egyiptomi lapos & 11,96 & 12,9 & 12,43 \\
\hline Konett & 12,78 & 9,68 & 11,23 \\
\hline On the mean of varieties & 12,27 & 11,90 & \\
\hline
\end{tabular}


Table 10. Variance table for total solids content

\begin{tabular}{|l|r|r|r|c|}
\hline \multicolumn{5}{|c|}{ Variance table (random block) - TOTAL SOLIDS } \\
\hline Factor & SQ & FG & MQ & F \\
\hline Total: & 144.24 & 71 & & \\
\hline Repetition: & 0.47 & 2 & & \\
\hline Treatment: & 131.99 & 23 & 5.74 & $22.40 * * *$ \\
\hline Factor A: & 86.89 & 11 & 7.90 & $30.83 * * *$ \\
\hline Factor B: & 2.38 & 1 & 2.38 & $9.29 * *$ \\
\hline Factors A B: & 42.72 & 11 & 3.88 & $15.16 * * *$ \\
\hline Error: & 11.79 & 46 & 0.26 & $* 26$ \\
\hline **** P=0,1\% & $* * * \mathrm{P}=1 \%$ & $* * \mathrm{P}=5 \%$ & $* \mathrm{P}=10 \%$ \\
\hline Significant differences: & & 0.83 \\
\hline Between any 2 combinations (P=5\%): & 0.59 \\
\hline Between A factor variants on the mean of B (P=5\%): & 0.24 \\
\hline Between B factor variants on the mean of A (P=5\%): & \\
\hline $\begin{array}{l}\text { Between differences (e.g. b1-b2 in different A variants) } \\
\text { (P=5\%): }\end{array}$ & \\
\hline
\end{tabular}

\section{Root quality evaluation}

Basic material as used for fresh market and the processing industry were evaluated by simple sensory methods (Table 11) to establish inner colour intensity, white ring and taste values. Parameters were evaluated by scores: $1-5$ in the case of inner red colour intensity. The competent compounds are mostly found in the rind and less in the xylem causing visible white or light coloured rings (scores: $1-3$ ). Sensory evaluation confirmed that those of the spring sowing. The difference is more pronounced in the late sowing date. There is close correlation between pigment quantities and distribution within the root as shown not only by sensory evaluation but by the correlation value between the 2 parameters $(r=0.730)$ as well (Table 5).

Modern diet stresses the importance of fresh vegetable consumption. Raw beet roots were also evaluated sensorially (1-5). In fresh salad dishes the taste of the basic material is decisive, only slightly modified by adding species. On the contrary, in processed food heat treatment and the composition of the brine can quite cover the original taste. Beside the sweet taste the presence of geosmin causing an earthy taste could also be evaluated by chewing raw root slices. There is no significant correlation between varieties of high sugar content and their sweet taste.

The earthy taste is due to microorganisms living in symbiosis with table beet roots, to the genetical character of the variety but also to soil factors (compactness, airless soil) which play a part in its development. In our trials values above 4.00 were mostly obtained in varieties of the spring sowing (Bonel, Rubin, Little Ball, Akela, Bikores and Konett). Of the 5 varieties in the late (August) sowing Mona Lisa excelled in flavour and aroma (5.00).

Table 11. Sensory evaluation results in beet root varieties

\begin{tabular}{|c|c|c|c|c|c|c|c|c|c|}
\hline Sowing date & \multicolumn{3}{|c|}{ Inner colour (1-5) } & \multicolumn{3}{|c|}{ White ring (1-3) } & \multicolumn{3}{|c|}{ Taste (1-5) } \\
\hline Variety & 15 April & 9 July & 19 August & 15 April & 9 July & 19 August & 15 April & 9 July & 19 August \\
\hline Detroit & 3,50 & & & 1,00 & & & 1,50 & & \\
\hline Bordó & 4,00 & 4,54 & & 2,50 & 2,71 & & 1,70 & 2,98 & \\
\hline Favorit & 5,00 & 4,65 & & 3,00 & 2,95 & & 3,00 & 3,13 & \\
\hline Rubin & 4,20 & 4,65 & & 2,50 & 3,00 & & 4,50 & 3,13 & \\
\hline Little Ball & 3,93 & 4,35 & & 1,90 & 2,60 & & 4,50 & 2,75 & \\
\hline Akela & 5,00 & 4,95 & 5,00 & 3,00 & 3,00 & 3,00 & 4,40 & 3,00 & 4,00 \\
\hline Larka & 4,93 & 4,93 & 5,00 & 2,50 & 2,93 & 3,00 & 3,17 & 2,77 & 3,00 \\
\hline Libero & 4,97 & 4,87 & 5,00 & 3,00 & 3,00 & 3,00 & 3,90 & 2,73 & 4,00 \\
\hline Mona Lisa & 4,77 & 4,70 & 5,00 & 3,00 & 3,00 & 3,00 & 3,83 & 2,88 & 5,00 \\
\hline Bikores & 4,17 & 4,50 & & 2,33 & 2,87 & & 4,43 & 3,23 & \\
\hline Egyipt. lapos & 3,87 & 3,93 & & 2,13 & 2,00 & & 3,40 & 2,50 & \\
\hline Konett & 4,80 & 4,33 & & 2,50 & 2,87 & & 4,27 & 3,33 & \\
\hline Cylindra & & 5,00 & & & 3,00 & & & 3,00 & \\
\hline C. podhlov. & & 4,07 & & & 3,00 & & & 2,33 & \\
\hline mean & 4,44 & 4,61 & 4,80 & 2,47 & 2,85 & 3,00 & 3,62 & 2,93 & 3,90 \\
\hline deviation & 0,52 & 0,34 & 0,45 & 0,57 & 0,27 & 0,00 & 1,03 & 0,29 & 0,74 \\
\hline scores & \multicolumn{3}{|c|}{$\begin{array}{l}1 \text { - red } \\
\downarrow \\
5 \text { - deep purple }\end{array}$} & \multicolumn{3}{|c|}{$\begin{array}{l}1 \text { - with white ring } \\
\downarrow \\
3 \text { - uniform inner colour }\end{array}$} & \multicolumn{3}{|c|}{$\begin{array}{l}1 \text { - strong earthy taste, tart after-taste } \\
\downarrow \\
5 \text { - sweet free of earthy taste }\end{array}$} \\
\hline
\end{tabular}




\section{References}

Feller, C. \& Fink, M. (2004): Nitrate content, soluble solids content, and yield of table beet as affected by cultivar, sowing date and nitrogen supply. HortScience 39 (6):1255-1259.

Goldman, I. L. \& Navazio, J. P. (2008): Table beet. [In: Handbook of Plant breeding. Vegetables I.] Ed.: Prohens, J and Nuez F. Springer, 219-238.

Guiping, L., Edwards, C. G., Fellman, J. K., Mattinson, D. S. \& Navasio, J. (2003): Biosynthetic origin of geosmin in red beets (Beta vulgaris L). J. Agric. Food Chem., 51 (4): 1026-1029.

Mabry T. J. (1980): Betalains. In Encyclopedia of plant physiology, newseries, vol.8. Secondary plant products. (Bell E. A., Charlwood, B. B., Edies.). Springer-Verlag, New York, 513-533 p.

Nagy-Gasztonyi M., Daood H., Takács Hájos M. \& Biacs P. A. (2001): Comparison of red-beet varieties on the basis of their pigment-components. Journal of the Science of Food and Agriculture. 81: 932-933.

Nilsson T. (1970): Studies into the pigments in beetroot. Lantbr. högsk. Anner. 36: 179-219.

Rasic, J. Lj., Bogdanovic, G. \& Kerenji,A. (1983): Gemüseseafre, Antikanzerogene Eigenschaften von milchsauer vergorenem RoteBete-Saft, Flüssiges Obst 1: 25-28

Shannon S., (1972): Changes in soluble solids, red pigments content and firmness of table beet cultivars with growing time and season. Journal of the American Society for Horticultural Science. 97: 223-228.

Sumrah M. A., Bakhsh A. \& Ahmad S. (2003): Effects of Sowing Time on Growth Behaviour of Beet Root in Sub-mountainous Climatic Conditions. Asian Journal of Plant Sciences. 2. (3): 354-357.
Stefanovits Bányai É., Kiss A. S., Csikkel Szolnoki A., Sz. Varga I. \& Takacs Hajos M. (2002): Phytochemical and macroelement stuty of Beta vulgaris L. ssp. esculenta var. rubra. Central European Journal of Occupational and Environmental Medicine. 8. (2-3): $167-171$.

Sváb J. (1981): Biometriai módszerek a mutatásban. Mezőgazdasági Könyvkiadó Vállalat, Budapest. 557. p.

Takácsné Hájos M. (1997a): The effect of sowing dates on parameters determing beet root quality. Horticultural Science. 29. (3-4): 87-92.

Takácsné Hájos M. (1997b): A cékla nitrát- és geozmin tartalmának változásai a betakarítástól a felhasználásig. Kertészeti és Élelmiszeripari Egyetem Közleményei. 56: 160-166.

Takácsné Hájos M. (1999): Colour components of different table beet varieties. International Journal of Horticultural Science. 5 . (3-4): 36-39.

Takács-Hájos M., Szabó L., Kastori, R., Pucarevic, M. \& Zeremski Skoric, Z. (2008): Evaluation of quality parameters of table beet varieties in baby beet production. VII. Alps-Adria Scientific Workshop. 28 April - 2 May, 2008. Stara Lesna. Szlovákia. Cereal Research Communications. 36: 1075-1079.

Takács-Hájos M (2009): The effect of heat on table beet (Beta vulgaris ssp. esculenta var. rubra) quality. VIII. Alps-Adria Scientific Workshop. 27 April - 2 May 2009. Neum, Bosnia-Herzegovina, Cereal Research Communications. 37: 221-224

Váli L., Stefanovits-Bányai É., Szentmihályi K., Fébel H., Sárdi É., Lugasi A. \& Blázovics A. (2007): Liver-protecting effects of table beet (Beta vulgaris var. rubra) during ischemia-reperfusion. Nutrition 23: 172-178. 